\title{
Slowing my collision course with burnout
}

\author{
Paul Martin, MD \\ Point Edward, ON, Canada
}

Cite as: Martin P. Slowing my collision course with burnout. Can Urol Assoc J 2021;15 (6Suppl1):S43. http://dx.doi.org/10.5489/cuaj.7230

$\square$

he emphasis on decreasing burnout and increasing wellness in the medical profession seems relatively recent, but the underlying ideas have been discussed for millenia. There are many examples, past and present, of philosophical theories that emphasize that knowledge of self, and living a simple life are preferable to a life of luxury with accumulation of wealth. I recently learned about Diogenes, a Greek founder of the cynic philosophy, who follows similar ideals. Diogenes was a contemporary of Alexander the Great. Many historians note the contrast between them, with Alexander being the richest and most powerful man in the world, and Diogenes living a simple life free of possessions. We are told the latter ultimately lead a longer and happier life. In the most famous encounter between them, Alexander asked what Diogenes would want if he could have anything, and Diogenes replied, "Stand a little out of my sun."

When I was a resident, I distinctly remember thinking that burnout and overwork were not a problem for me and should not be a problem for anyone. I knew what I signed up for and I knew it would be rough. I used to say that if residency wasn't very hard, then you weren't doing it right. I also used to tell the medical students, "Lunch is a sign of weakness," and other similar things. It was a joke, but not really.

After residency, I just kept on going at the same pace; I really didn't slow down at all. Long days, lots of on-call,

doing cases at night even when I wasn't on-call, endless paperwork. As expected, I took care of many patients, and I made lots of money. I didn't spend much time with my kids. According to the Toronto Star, I was one of the top billers in the province that year (2018, five years into practice). It was ridiculous really; nobody needs that kind of money. For some reason, my impression was that most of my colleagues were working as hard as I was. It turned out, quite objectively, that I was wrong.

With that knowledge, as well as a desire to spend more time with my kids, and recently a forced slowdown for the pandemic, I am working much less than I used to and I am not going back. I never truly realized the extent that I was overdoing it until I was looking back. It's obvious that I was on a collision course with burnout and that my family was suffering for it.

I now work less, spend more time with my family, make less money, and I've never been happier. Of course, for others, the solution to burnout won't be as simple as "work less," but that was unquestionably the biggest part of it for me.

I may try to embrace even more of the traditional cynic philosophy, although I should mention that Diogenes chose to live in a barrel among the dogs, so maybe I won't take it that far!

Correspondence: Dr. Paul Martin, Point Edward, ON, Canada; pmartin.urology@gmail.com 